\title{
Effect of Intercropping on the Incidence of Gram Pod Borer, Helicoverpa armigera in Chickpea
}

\author{
M.A. Waseem*, Sobita Simon and Sasya Thakur \\ Department of Entomology, SHUATS, Allahabad - 211007, U.P., India \\ *Corresponding author
}

\begin{abstract}
Keywords Agriculture and Technology Science, to compare various combinations of chickpea intercropping. Among all the intercrop and chloropyriphos treatments, lowest per cent pod damage was recorded in chloripyrphos treatment with 4.83 and it was followed by chickpea + marigold, chickpea + mustard, chickpea + coriander and chickpea + linseed with $10.24,12.49,14.64$ and 16.77 per cent pod damage respectively. Chickpea sole was found with highest pod damage per cent. Data on intercropped chickpea equivalent yield revealed that, the highest yield was recorded in chlorpyriphos treated treatment of $19.48 \mathrm{q}$ $\mathrm{ha}^{-1}$, Followed by Chickpea + Marigold, Chickpea + Wheat, Chickpea + Coriander and Chickpea + Mustard with 19.13, 16.55, 16.43 and $15.52 \mathrm{q} \mathrm{ha}^{-1}$ respectively. Chickpea sole was recorded with $14.28 \mathrm{q} \mathrm{ha}^{-1}$. The highest cost benefit ratio was recorded in chlorpyriphos, Followed by Chickpea intercropped with Coriander, Marigold, Mustard and Lentil. Among the all treatment highest cost benefit ratio was recorded in Chickpea + Coriander (1:2.93), followed by lowest Chickpea + Wheat (1:2.22). All treatments are significant.
\end{abstract} nine treatments was carried out in investigation field of Sam Higginbottom University of

\section{Introduction}

In Uttar Pradesh, the $H$. armigera causes serious damage to the crop during fruiting stage and is considered to be a major limiting factor for the production of chickpea. Single larvae may destroy several pods before reaching to maturity and this pest is reported to damage 5 to 40 per cent pods of chickpea crop during different year (Chauhan and Dahiya, 1994). The moth begins ovipositing on chickpea at the seedling stage but this behavior is checked by the adverse climatic and geographical conditions (Tahhan et al., 1982). The caterpillars feed on flowers if suitable vegetation is not available (Patel and
Koshiya, 1999). It attacks more than 180 cultivated species from cereals, legumes, vegetables, fruits, forage and wild species (Jat and Ameta, 2013).

Crop pest surveillance and its monitoring aids in successful pest management strategies. It enables the growers to get prepared for necessary management measures taken against the pest. Intercropping is an ideal cropping for insect pest management at no additional cost. It acts as a preventive measure against build-up of insect pest population and is compatible with other 
methods of pest control and free from environmental pollution problems. It has considerable impact on egg laying, larval population, larval parasitisation and pod damage (Kumar et al., 2008).

Intercropping can affect microclimate of the agro ecosystem and ultimately produce an unfavourable environment for the pest. So, present research was carried on these objectives.

\section{Materials and Methods}

Evaluation of intercrops for the management of gram pod borer in chickpea was carried out during rabi 2016-17 at agriculture research farm, SHUATS, Allahabad. Chickpea cultivar Radhey was intercropped with marigold (3:1), coriander (5:1), pea (3:1), wheat (3:1), mustard (3:1), linseed (3:1), lentil (3:1), chloropyriphos and chickpea sole.

The experiment was laid out in randomised block design with plot size of $2 \times 2 \mathrm{~m}$. At harvest, pod damage per cent was worked out, grain yield, chickpea equivalent yield and economics were recorded treatment wise after threshing the pods.

\section{Results and Discussion}

To evaluate the different intercrops on percentage pod damage, grain yield and equivalent yield

The data on the pod damage per cent revealed that all the intercrop treatments and chloropyriphos treatment were significantly superior over the chickpea sole crop.

Among all the intercrop treatments and chloropyriphos treatment, lowest per cent pod damage was recorded in chloropyriphos treatment with 4.83 and found among and it was followed by chickpea + marigold, chickpea + mustard, chickpea + coriander and chickpea + linseed with $10.24,12.49,14.64$ and 16.77 per cent pod damage respectively. The next best treatments were, chickpea + lentil (19.90) and chickpea + wheat with 20.58 and 21.63 per cent pod damage respectively and they were found at par with each other.

Intercropping chickpea + pea was found insignificant for the management of gram pod borer. Chickpea sole was found to be predominantly affected by highest pod damage per cent compared to other treatments with 32.44 per cent (Table 1).

Data on grain yield revealed that, the highest grain yield was recorded in chlorpyriphos treated treatment of $19.48 \mathrm{q} \mathrm{ha}^{-1}$. Followed by Chickpea + Marigold $\left(14.71+4.42 \mathrm{q} \mathrm{ha}^{-1}\right)$, Chickpea + Coriander $\left(13.42+3.01 \mathrm{q} \mathrm{ha}^{-1}\right)$ and Chickpea + Mustard $\left(13.42+2.10 \mathrm{q} \mathrm{ha}^{-1}\right)$.

The next best yields were recorded by the following treatments Chickpea + linseed $\left(11.88+2.42 \mathrm{q} \mathrm{ha}^{-1}\right)$, Chickpea + Wheat $\left(10.57+5.98 \mathrm{q} \mathrm{ha}^{-1}\right)$ and Chickpea + Lentil $\left(10.24+4.98 \mathrm{q} \mathrm{ha}^{-1}\right)$. Chickpea + Pea $(9.54+$ $0.32 \mathrm{q} \mathrm{ha}^{-1}$ ) intercrop was found with lower yield. Chickpea sole was recorded with 14.28 $\mathrm{q} \mathrm{ha}^{-1}$.

Data on intercropped chickpea equivalent yield revealed that, the highest grain yield was recorded in chlorpyriphos treated treatment of $19.48 \mathrm{q} \mathrm{ha}^{-1}$. Followed by Chickpea + Marigold, Chickpea + Wheat, Chickpea + Coriander and Chickpea + Mustard with 19.13, 16.55, 16.43 and $15.52 \mathrm{q}$ $\mathrm{ha}^{-1}$. The next best yields were recorded by the following treatments i.e. Chickpea + lentil and Chickpea + Linseed with 15.22 and 14.30 $\mathrm{q} \mathrm{ha}^{-1}$. Chickpea + Pea intercropped treatment found with least yield compared to others with $10.85 \mathrm{q} \mathrm{ha}^{-1}$. Chickpea sole was recorded with $14.28 \mathrm{q} \mathrm{ha}^{-1}$ (Table 2). 
Table.1 To evaluate the different intercrops on percentage pod damage, grain yield and equivalent yield

\begin{tabular}{|l|l|l|c|c|c|}
\hline S.No & $\begin{array}{l}\text { T. } \\
\text { No. }\end{array}$ & Treatments & $\begin{array}{l}\text { Pod } \\
\text { damage } \\
\mathbf{\%}\end{array}$ & Grain yield & $\begin{array}{l}\text { Chickpea } \\
\text { equivalent yield } \\
\text { (CEY) }\left(\mathbf{q h a} \mathbf{- 1}^{\mathbf{1}}\right.\end{array}$ \\
\hline 1. & $\mathbf{T}_{\mathbf{1}}$ & Chickpea + Marigold & 10.24 & $14.71+4.42$ & 19.13 \\
\hline 2. & $\mathbf{T}_{\mathbf{2}}$ & Chickpea + Coriander & 14.64 & $13.42+3.01$ & 16.43 \\
\hline 3. & $\mathbf{T}_{\mathbf{3}}$ & Chickpea + pea & 27.38 & $8.28+2.57$ & 10.85 \\
\hline 4. & $\mathbf{T}_{\mathbf{4}}$ & Chickpea + Wheat & 21.63 & $10.57+5.98$ & 16.55 \\
\hline $\mathbf{5 .}$ & $\mathbf{T}_{\mathbf{5}}$ & Chickpea + Mustard & 12.49 & $13.42+2.10$ & 15.52 \\
\hline 6. & $\mathbf{T}_{\mathbf{6}}$ & Chickpea + Linseed & 16.77 & $11.88+2.42$ & 14.30 \\
\hline 7. & $\mathbf{T}_{\mathbf{7}}$ & Chickpea + Lentil & 20.58 & $10.24+4.98$ & 15.22 \\
\hline 8. & $\mathbf{T}_{\mathbf{8}}$ & Chloropyriphos & 04.83 & 19.48 & 19.48 \\
\hline 9. & $\mathbf{T}_{\mathbf{9}}$ & Sole chickpea & 32.44 & 14.28 & 14.28 \\
\hline F test & & $\mathrm{S}$ & $\mathrm{S}$ & $\mathrm{S}$ \\
\hline SeD & & 0.35 & 0.15 & 0.62 \\
\hline CD & & 0.75 & 0.31 & 1.33 \\
\hline
\end{tabular}

Table.2 Economics of chickpea pod borer management using different treatments

\begin{tabular}{|l|l|l|l|l|l|l|}
\hline $\begin{array}{l}\text { Sr. } \\
\text { No. }\end{array}$ & Treatment & $\begin{array}{l}\text { Total cost } \\
\text { of seed or } \\
\text { treatment }\end{array}$ & $\begin{array}{l}\text { Common } \\
\text { cost }\end{array}$ & Total cost & $\begin{array}{l}\text { Gross } \\
\text { returns }\end{array}$ & C:B ratio \\
\hline 01 & $\begin{array}{l}\text { Chickpea }+ \\
\text { Marigold }\end{array}$ & 3640 & 23248 & $\mathbf{2 6 8 8 8}$ & $\mathbf{7 7 9 7 0}$ & $\mathbf{1 : 2 . 8 9}$ \\
\hline $\mathbf{0 2}$ & $\begin{array}{l}\text { Chickpea }+ \\
\text { Coriander }\end{array}$ & 3950 & 23248 & $\mathbf{2 7 1 9 8}$ & $\mathbf{7 9 7 4 2}$ & $\mathbf{1 : 2 . 9 3}$ \\
\hline $\mathbf{0 3}$ & Chickpea + pea & 7200 & 23248 & $\mathbf{3 0 4 4 8}$ & $\mathbf{4 5 2 5 5}$ & $\mathbf{1 : 1 . 4 8}$ \\
\hline $\mathbf{0 4}$ & $\begin{array}{l}\text { Chickpea }+ \\
\text { Wheat }\end{array}$ & 4850 & 23248 & $\mathbf{2 8 0 9 8}$ & $\mathbf{6 2 4 1 8}$ & $\mathbf{1 : 2 . 2 2}$ \\
\hline $\mathbf{0 5}$ & $\begin{array}{l}\text { Chickpea }+ \\
\text { Mustard }\end{array}$ & 3675 & 23248 & $\mathbf{2 6 9 2 3}$ & $\mathbf{7 4 4 5 0}$ & $\mathbf{1 : 2 . 7 6}$ \\
\hline $\mathbf{0 6}$ & $\begin{array}{l}\text { Chickpea }+ \\
\text { Linseed }\end{array}$ & 3922 & 23248 & $\mathbf{2 7 1 7 0}$ & $\mathbf{7 0 6 5 3}$ & $\mathbf{1 : 2 . 6 0}$ \\
\hline $\mathbf{0 7}$ & $\begin{array}{l}\text { Chickpea }+ \\
\text { Lentil }\end{array}$ & 3915 & 23248 & $\mathbf{2 7 1 6 3}$ & $\mathbf{7 2 1 1 6}$ & $\mathbf{1 : 2 . 6 5}$ \\
\hline $\mathbf{0 8}$ & Chloropyriphos & 6575 & 23248 & $\mathbf{2 9 8 2 3}$ & $\mathbf{9 7 4 0 0}$ & $\mathbf{1 : 3 . 2 6}$ \\
\hline $\mathbf{0 9}$ & Chickpea sole & 4800 & 23248 & $\mathbf{2 8 0 4 8}$ & $\mathbf{7 1 4 0 0}$ & $\mathbf{1 : 2 . 5 4}$ \\
\hline
\end{tabular}




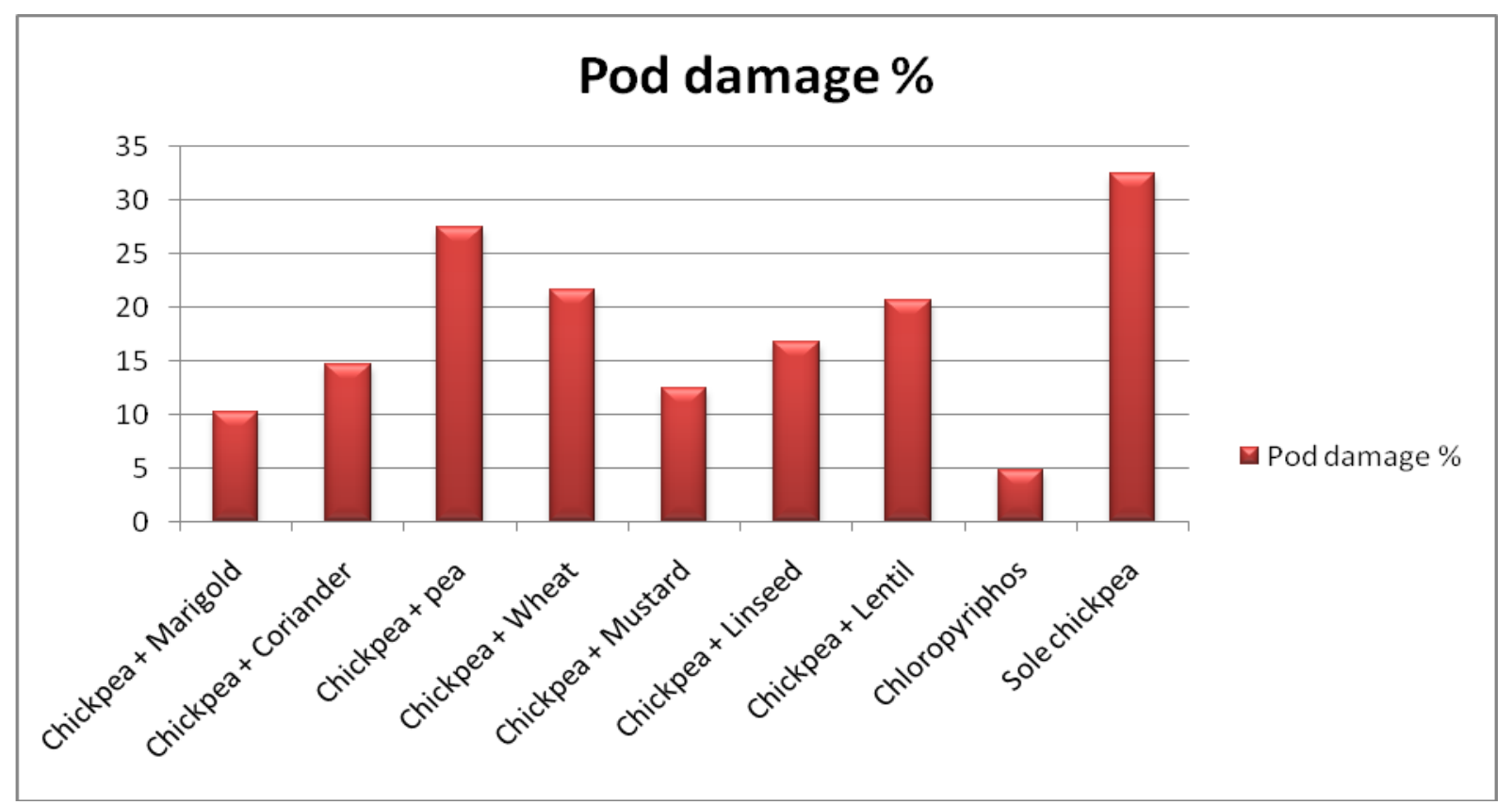

Data on intercropped chickpea equivalent yield revealed that, the highest cost benefit ratio was recorded in chlorpyriphos treated treatment of 3.26. Followed by Chickpea + Coriander, Chickpea + Marigold, Chickpea + Mustard and Chickpea + Lentil with 2.93, $2.89,2.76$ and 2.65. The next best yields were recorded by the following treatments i.e. Chickpea + linseed and Chickpea sole with 2.60 and 2.54. Chickpea + Wheat and Chickpea + Pea intercropped treatment found with cost benefit ratio compared to Chickpea sole with 2.22 and 1.48. Chickpea + Pea were found uneconomical among the treatments.

Effectiveness of chlorpyriphos was higher than the other insecticides in reducing pod damage and recorded significantly higher good pods per plant and it was reported by Gowada et al., (2007). The effectiveness of chlorpyriphos was significantly superior in all treatment, reported by Balasubramanian et al., (2001), Gowada et al., (2007), Shahzad et al., (2003) and Shah et al., (2003). Yadav (1989) and Kumar et al., (2008) mixed crop with marigold and coriander found reduced gram pod borer population and per cent pod damage. The other authors also supported our present investigation that chickpea intercropped cropped with mustard or linseed has been observed with reduced gram pod borer damage Lal et al., (1985), Yadav, (1989), Singh (2014) and Yadav, (1987). Chickpea + marigold were recorded with maximum yield which was at par with the Chickpea + coriander by Tripathi et al., (2008).

Hossain et al., (2010) revealed that, chickpea intercropped with mustard was most economic module for the management of gram pod borer with early sowing as, marigold used as trap crop reducing the egg laying of gram pod borer in tomato which was reported by Srinivasan et al., (1994).

Hanumantharaya et al., (2007) and Turker et al., (2000) reported that intercropping also increases the natural enemies on gram pod borer than compared to sole crop. Reena et al., (2009) also concluded that gram pod borer population can be effectively managed by intercropping with mustard, coriander and linseed. Certain findings of our present investigation were similar with Pankaj et al., 2008 and Gughal et al., 2013. 


\section{References}

Chauhan, R., and Dahiya, B. 1994. Response of different chickpea genotypes to $H$. armigera at Hisar. Indian J. Plant Protection. 22: 170- 72.

Ghugal, S. G., Shrivastava, S. K., Bhowmick, A. K. and Saxena, A. K. 2013. Management of Helicoverpa armigera (Hubner) in chickpea with biopesticides. JNKVV Res. J., 47(1): 8487.

Gowda, S. D. K., Patil, B. V., and Yelshetty, S. 2007. Performance of Different Sprayers against Gram Pod Borer, Helicoverpa armigera (Hubner) on Chickpea. Karnataka J. Agric. Sci., 20(2): 261-264.

Hanumantharaya, L., Venkateshalu, Kubasad V. S and Raju S. G. 2007. Role of cropping pattern for the management of insect pests of Safflower, Carthamus tinctorius $L .7^{\text {th }}$ international safflower conference, AICRP (Safflower) Agricultural Research Station, Annigeri, Karnataka.

Hossain, M.D., A., Haque, MD. A., Ahmad, M. and Prodhan, M. Z. H. 2010. Development of an integrated management approach for pod borer, Helicoverpa armigera (Hubner) on chickpea. Bangladesh J. Agril. Res., 35 (2): 201-206.

Jat, S. K., and Ameta, O. P. 2013. Relative efficacy of biopesticides and newer insecticides against Helicoverpa armigera (Hub.) in tomato. The Bioscan. 8(2): 579-582.

Kumar, P., Singh, R. S. and Bisen, R. S. 2008. Effect of intercropping on gram pod borer incidence in chickpea. Journal of Food Legume, 21(2): 135-136.

Lal, S. S., Sachan, J. N. and Chandra, S. 1985. Cultural and varietal tools for integrated pest management for increasing pulse production. Plant Protection Bulletin,
37: 111 .

Pankaj, K., Singh, R. S. and Bisen, R. S. 2008. Effect of intercropping on gram pod borer incidence in chickpea. Food Legumes, 21(2):135-136

Patel, C. C., and Koshiya, D. J. 1999. Population dynamics of gram pod borer, $H$. armigera Hardwick on cotton, pigeon pea and chickpea. Gujarat Agricultural University Research J. 24: 62-67.

Reena, Singh, S. K., Sinha, B. K., Jamwal, B. S. 2009. Management of gram pod borer, Helicoverpa armigera (Hubner) by intercropping and monitoring through pheromone traps in chickpea. Karnataka J Agric Sci., 22(3):524-526

Shah, Zahid Ali, Muhammad K Ashif Shahzad and Muhammad Asif Sharaz. 2003. Efficacy of Different Insecticides against Larval Population Density of Gram Pod Borer, Helicoverpa armigera (Hub.) with reference to Chickpea in Faisalabad-Pakistan. International Journal of Agriculture \& Biology, 5 (3): 326-328.

Singh, D., Singh, S. K. and Vennila, S. 2015. Weather parameters influence population and larval parasitization of Helicoverpa armigera (Hubner) in chickpea ecosystem. Legume Research, 38 (3): 402-406.

Singh, R., and Ali, S. 2006. Seasonal incidence of Helicoverpa armigera and Campoletis chlorideae on chickpea. Annals of Plant Protection Science, 14 (1): 234-235.

Singh, S. K., 2014. Usefulness of intercrops in management of African Bollworm, Helicoverpa armigera Hubner in chickpea, Cicer arietinum L. in Ethiopia. J. of Food Legumes, 27 (3): 226-229.

Singh, S. S., and Yadav, S. K. 2007. Comparative efficacy of insecticides, biopesticides and neem formulations 
against $H$. armigera on chickpea. Ann. Pl. Protec. Sci. 15(2): 299-302.

Tahhan, O., Sithanantham, S., Hariri, G. and Reed, W. 1982. Heliothis species infesting chickpeas in northern Syria. Int. Chickpea News Letter. 6: 21.

Turkar, K. S., Gupta, R., Banergee, S. K., Wangan, R. R. 2000. Influence of chickpea intercropping with coriander of parasitazation of Helicoverpa armigera (Hub.) by Campoletis chlorideae (Uchida). J Entomo Res., 24 (3):279-281.

Yadav, C. P., 1989. National Symposium on New Frontiers in Pulses Research and Development, Nov. 10-12, 1989, ISPRD, Directorate of Pulses Research, Kanpur Wilken, G.C. 1972. Geographic Review, 62

\section{How to cite this article:}

Waseem, M.A., Sobita Simon and Sasya Thakur. 2017. Effect of Intercropping on the Incidence of Gram Pod Borer, Helicoverpa armigera in Chickpea. Int.J.Curr.Microbiol.App.Sci. 6(10): 2619-2624. doi: https://doi.org/10.20546/ijcmas.2017.610.308 